\title{
Cytogenetic microarray in prenatal and postnatal diagnosis
}

\author{
Shubha Phadke \\ From International Conference on Human Genetics and 39th Annual Meeting of the Indian Society of \\ Human Genetics (ISHG) \\ Ahmadabad, India. 23-25 January 2013
}

Due to high resolution cytogenetic microarray (CMA) has replaced traditional karyotyping for evaluation of individuals with intellectual disability, autism and congenital malformations. The diagnostic yield of CMA is 10 to $12 \%$ and is more than any other investigation for evaluation of developmental disabilities. Due to its high resolution CMA is also being used as a prenatal test for chromosomal anomalies. The diagnostic yield is about $3 \%$ whatever may be the indication. The yield is higher in cases with fetal anomalies. The main concern with CMA is its ability detection of copy number variations of unknown significance. This is a major problem in prenatal diagnosis and is a challenge for the counselor and dilemma for the family in concern. With accumulation of more and more data of pathological and polymorphic variations in genome the variations of unknown significance will decrease. CMA is also useful in delineating abnormalities picked up by karyotyping. Some cases with double segment rearrangement may point towards familial chromosomal rearrangement and hence, CMA is indicated in familial cases with developmental disabilities and birth defects.

Cost and availability of clinical cytogeneticists for appropriate interpretation of CMA results are important concerns for wider application of the technique.

Published: 21 January 2014

doi:10.1186/1755-8166-7-S1-I32

Cite this article as: Phadke: Cytogenetic microarray in prenatal and

postnatal diagnosis. Molecular Cytogenetics 2014 7(Suppl 1):132.

Correspondence: shubharaophadke@gmail.com

Department of Medical Genetics, SGPGIMS, Lucknow, India

Submit your next manuscript to BioMed Central and take full advantage of:

- Convenient online submission

- Thorough peer review

- No space constraints or color figure charges

- Immediate publication on acceptance

- Inclusion in PubMed, CAS, Scopus and Google Scholar

- Research which is freely available for redistribution

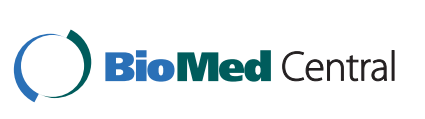

(C) 2014 Phadke; licensee BioMed Central Ltd. This is an Open Access article distributed under the terms of the Creative Commons Attribution License (http://creativecommons.org/licenses/by/2.0), which permits unrestricted use, distribution, and reproduction in any medium, provided the original work is properly cited. The Creative Commons Public Domain Dedication waiver (http:// creativecommons.org/publicdomain/zero/1.0/) applies to the data made available in this article, unless otherwise stated. 